J. chron. Dis. 1964, Vol. 17, pp. 397-404. Pergamon Press Ltd. Printed in Great Britain

\title{
RELATION BETWEEN CASUAL BLOOD PRESSURE READINGS IN YOUTH AND AT AGE 40
}

\section{A RETROSPECTIVE STUDY}

\author{
S. Julius, M.D.*, E. Harburg, Ph.D., N. F. McGinn, Ph.D., J. Keyes $\dagger$ and \\ S. W. HOOBLER, M.D. \\ The Department of Internal Medicine and The Program of Social Psychology, University \\ of Michigan, Ann Arbor, Michigan
}

(Received 22 July 1963)

IT is often believed that a transient or sustained systolic blood pressure in excess of 140 $\mathrm{mm} \mathrm{Hg}$ in youth denotes that the young person is a candidate for later development of hypertensive vascular disease. The present study attempts to examine this postulate more closely. Records of a single casual blood pressure taken in the course of routine physical examinations during the period 1939-1942 at the University of Michigan Health Service were made available to usł. Furthermore the present whereabouts of most of these individuals could be traced from records kept in the University Alumni Office.

\section{E T H O D S}

Two hundred and forty white male graduates from the schools of medicine, dentistry, and engineering, living within a radius of approximately 100 miles of Ann Arbor and known to have been examined in 1939-1942 on entrance to the University of Michigan were selected from files at the Alumni Office. They were asked by correspondence to provide us with their current blood pressure. These readings might be either those recorded within the previous year by their local physician or as obtained and forwarded to us for the purpose of the study. The subject was also requested to furnish information concerning his present body weight, height, present health, history of hypertension, or of cardiovascular disease. Useful data were received from 208 individuals of the 240 contacted. In these, 70 per cent of the current blood pressure readings were mailed to us from the local physician's records, 16 per cent from other hospital or health service records, and 14 per cent directly from the subjects, many of whom were physicians. The average time of follow-up was 20 years.

\footnotetext{
*Present address : Department of Internal Medicine, University Medical School, Rebro, Zagreb, Yugoslavia.

†Undergraduate trainee, Cardiovascular Training Grant HTS 5465 U.S. Department of Health, Education and Welfare.

$\$$ We wish to thank Dr. Morley Beckett, Director of the Student Health Service, for assistance in obtaining the records used in this study and the staff of the University of Michigan Alumni Office for providing us with current addresses.
} 
At the first readings the students' average age was 19.8 years (range 17-21) and at time of follow-up was 40.1 years (range 36-43).

No claim is made that our results are representative of college graduate males, therefore several characteristics of the group should be noted. Their original blood pressure level would be considered within normal limits (121/76 mm Hg). About 25 per cent had a systolic pressure less than $111 \mathrm{~mm} \mathrm{Hg}$, while 13 per cent had levels over $130 \mathrm{~mm} \mathrm{Hg}$. As students, 81 per cent were either normal or underweight when judged according to Metropolitan Life Insurance standards. The group was homogeneous: college-graduated, professionally occupied, white males of similar age.

\section{O B S E R V A T I O N S}

Blood pressure levels as students and 20 years later are summarized in Table 1 and Figs. 1 and 2. Groups with a low average blood pressure as students tended to show higher readings 20 years later while those with higher initial readings tended to be lower at follow-up; these changes are interpreted as a 'regression toward the mean.' They may also serve to emphasize the inadequacy of single casual readings as a basis for classification of blood pressure levels. Nevertheless, some correlation between the early and the current blood pressure reading should be noted. Systolic pressure taken in student days correlated better with the present diastolic level $(r=0.22 ; P<0.05)$ than with the present systolic reading $(r=0.06)$. Diastolic pressure taken in student days showed some correlation with present diastolic levels $(r=0.16 ; P<0.05)$ but not with current systolic measurements $(r=-0.07)$.

TABle 1. Relationship of JUVENILE AND PResent bloOd pressure levels (means) in a male AGE-CONTROLLED 20-YEAR COHORT

\begin{tabular}{|c|c|c|c|c|c|c|}
\hline & $\begin{array}{l}\text { Juvenile } \\
\text { systolic } \\
\text { levels }\end{array}$ & Number & $\begin{array}{l}\text { Present } \\
\text { systolic }\end{array}$ & $\begin{array}{l}\text { Present } \\
\text { diastolic }\end{array}$ & $\begin{array}{l}\text { Change in } \\
\text { systolic }\end{array}$ & $\begin{array}{l}\text { Change in } \\
\text { diastolic }\end{array}$ \\
\hline & $\begin{array}{c}<101 \\
101-110 \\
111-120 \\
121-130 \\
131-140 \\
141-150 \\
>150-120.8\end{array}$ & $\begin{array}{r}9 \\
40 \\
70 \\
62 \\
17 \\
5 \\
5\end{array}$ & $\begin{array}{l}117.0 \\
123.7 \\
124.0 \\
127.0 \\
129.5 \\
138.4 \\
134.0\end{array}$ & $\begin{array}{l}75.8 \\
77.0 \\
79.1 \\
80.8 \\
81.3 \\
87.2 \\
84.0\end{array}$ & $\begin{array}{l}+16.0 \\
+12.0 \\
+6.8 \\
+2.8 \\
-7.5 \\
-7.4 \\
-21.0\end{array}$ & $\begin{array}{l}+11.0 \\
+7.8 \\
+\quad 3.5 \\
+2.6 \\
-4.2 \\
+0.5 \\
-1.0\end{array}$ \\
\hline \multirow[t]{3}{*}{ Average } & & 208 & 125.6 & 79.6 & +4.8 & +3.6 \\
\hline & $\begin{array}{l}\text { Juvenile } \\
\text { diastolic } \\
\text { levels }\end{array}$ & & & & & \\
\hline & $\begin{array}{c}<61 \\
61-70 \\
71-80 \\
81-90 \\
>90-76.0\end{array}$ & $\begin{array}{r}8 \\
52 \\
89 \\
52 \\
7\end{array}$ & $\begin{array}{l}119.6 \\
123.2 \\
126.4 \\
126.8 \\
130.0\end{array}$ & $\begin{array}{l}72.2 \\
78.0 \\
79.9 \\
80.6 \\
83.7\end{array}$ & $\begin{array}{l}+11.6 \\
+8.0 \\
+\quad 7.0 \\
-1.7 \\
-8.7\end{array}$ & $\begin{array}{l}+14.7 \\
+10.5 \\
+4.0 \\
-4.9 \\
-8.1\end{array}$ \\
\hline Average & & 208 & 125.6 & 79.6 & +4.8 & +3.6 \\
\hline
\end{tabular}




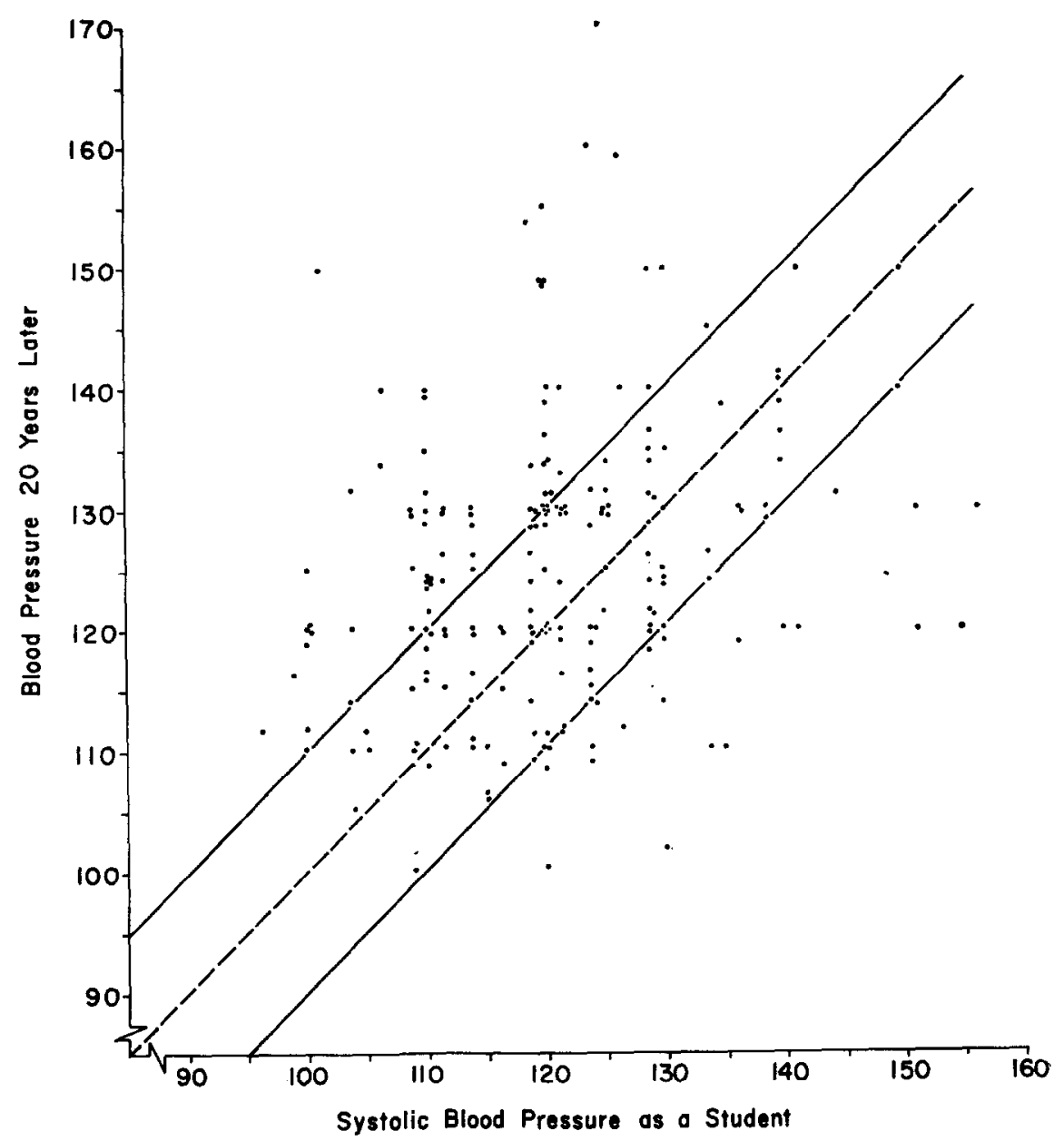

FIG. 1. Correlation of juvenile and adult systolic blood pressures $(r=0.06)$. Limits of $10 \mathrm{~mm}$ increase (upper quadrant) or of $10 \mathrm{~mm}$ decrease (lower quadrant) delimited by the solid lines. If there had been no change in the blood pressure over the time interval of study, all points would fall on the interrupted center line.

Table 2 shows that there was little relation between juvenile blood pressure and the frequency of subsequent 'hypertension' when defined as a systolic blood pressure of 150 $\mathrm{mm} \mathrm{Hg}$ or more and/or a diastolic level of $90 \mathrm{~mm} \mathrm{Hg}$ or more. The blood pressures of 10 of the 29 current 'hypertensives' are $150 \mathrm{~mm} \mathrm{Hg}$ or more systolic while all but five are $90 \mathrm{~mm} \mathrm{Hg}$ or more diastolic. The average age of the 'hypertensives' is 40.5 , not significantly different from the age of the remainder (39.9) at time of follow-up.

We found 27 cases with blood pressure levels in excess of $139 \mathrm{~mm} \mathrm{Hg}$ systolic or 89 $\mathrm{mm} \mathrm{Hg}$ diastolic in youth. Of these, 7 showed 'hypertension' (over $149 \mathrm{~mm} \mathrm{Hg}$ or over $89 \mathrm{~mm} \mathrm{Hg}$ ) later in life, but except in 3 cases there has been no substantial increase. The juvenile and adult blood pressure readings in these seven cases were: 160/86$170 / 100,142 / 90-150 / 100,140 / 90$ - 142/92, 138/94-128/90, 128/94 - 150/84, 126/90$159 / 120,126 / 90-140 / 90$. Of 9 cases in which both systolic and diastolic juvenile 


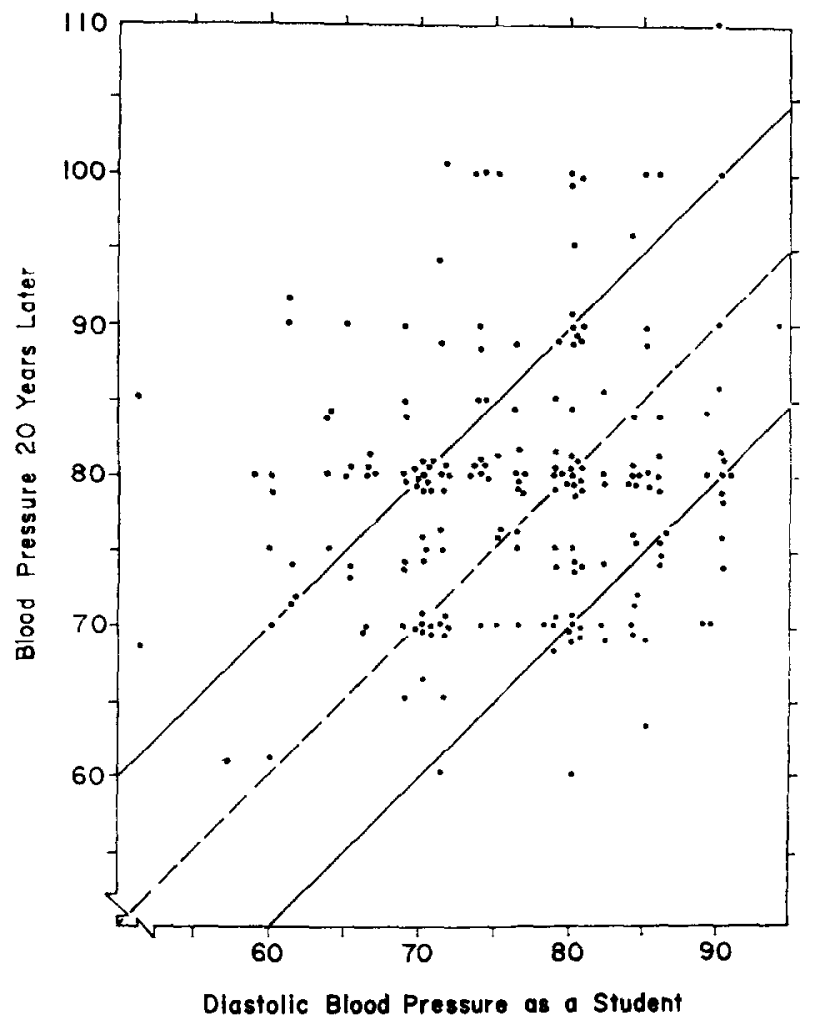

Fig. 2. Correlation of juvenile and adult diastolic blood pressures $(r=0 \cdot 16)$.

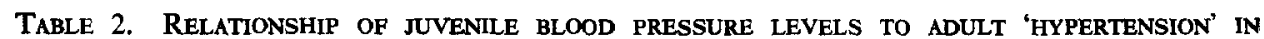
AN AGE-CONTROLLED 20-YEAR COHORT

\begin{tabular}{|c|c|c|c|c|c|c|}
\hline & & & Ele & 1 adult & pressu & \\
\hline & systolic & No. & Systolic & diastolic & & \\
\hline & & & No. & $\%$ & No. & $\%$ \\
\hline & $<101$ & 9 & 0 & 0 & 0 & 0 \\
\hline & $101-110$ & 40 & 6 & 15 & 1 & 3 \\
\hline & $111-120$ & 70 & 7 & 10 & 2 & 3 \\
\hline & $121-130$ & 62 & 11 & 18 & 4 & 6 \\
\hline & $13 l-140$ & 17 & 2 & 12 & 0 & 0 \\
\hline & $141-150$ & 5 & 2 & 40 & 1 & 20 \\
\hline & $>150$ & 5 & 1 & 20 & 1 & 20 \\
\hline Total & & 208 & 29 & 14 & 9 & 4 \\
\hline & $\begin{array}{c}\text { Juvenile } \\
\text { diastolic } \\
\text { levels }\end{array}$ & & & & & \\
\hline & $<61$ & 8 & 0 & 0 & 0 & 0 \\
\hline & $61-70$ & 52 & 6 & 11 & 3 & 6 \\
\hline & $71-80$ & 89 & 13 & 15 & 3 & 3 \\
\hline & $81-90$ & 52 & 8 & 15 & 3 & 6 \\
\hline & $>90$ & 7 & 2 & 28 & 0 & 0 \\
\hline Total & & 208 & 29 & 14 & 9 & 4 \\
\hline
\end{tabular}

"Elevation' is defined as a current reading of $150 \mathrm{~mm} \mathrm{Hg}$ and over (systolic) and/or $90 \mathrm{~mm} \mathrm{Hg}$ or over (diastolic). 
blood pressure levels were high, 2 exhibit high readings, as adults; of 11 subjects with only diastolic elevations in youth, 4 exhibit later 'hypertension'; of 8 with juvenile systolic blood pressure elevations, 2 as adults show an abnormal reading. If a juvenile diastolic reading above $89 \mathrm{~mm} \mathrm{Hg}$ be taken as evidence of 'prehypertension.' then 6 of 19 youthful 'prehypertensives' ( 32 per cent) exbibit some degree of blood pressure elevation at age 40 . This is to be contrasted with an overall incidence of 14 per cent in the 208 subjects who were followed over the 20 -year interval, and a frequency of 13 per cent in 149 subjects with a juvenile diastolic reading below $81 \mathrm{~mm} \mathrm{Hg}$.

It is recognized that the definition of 'hypertension' in the adult was quite arbitrary. In 11 cases the only reason for classifying the subject as hypertensive was a diastolic blood pressure of $90 \mathrm{~mm} \mathrm{Hg}$. Of all 29 adult 'hypertensives,' 5 exhibited diastolic and 2 systolic abnormalities in youth. In 7 of the adult cases the readings are sufficiently high as to suggest the presence of hypertension of possible future clinical importance; 3 of these 7 showed a slight deviation from normal in youth. The juvenile and current readings in these cases are as follows: $125 / 70-170 / 110,160 / 86-170 / 100,124 / 74$ $160 / 90,126 / 90-159 / 120,120 / 80-155 / 90,118 / 80-154 / 100,142 / 90-150 / 100$.

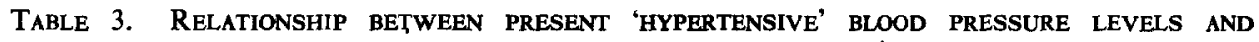
IDEAL WEIGHTS AS STUDENT AND ADULT*

\begin{tabular}{|c|c|c|c|c|c|}
\hline \multirow{2}{*}{\multicolumn{2}{|c|}{ Ideal weight }} & \multicolumn{4}{|c|}{ Present blood pressure levels (\%) } \\
\hline & & \multicolumn{2}{|c|}{$\begin{array}{l}\text { Normotensive } \\
(n=160)\end{array}$} & \multicolumn{2}{|c|}{$\begin{array}{l}\text { Hypertensive } \dagger \\
(n=29)\end{array}$} \\
\hline \multicolumn{3}{|c|}{$\begin{array}{l}\text { As students } \\
8 \mathrm{lb} \text { underweight } \\
\text { Normal } \\
8 \mathrm{lb} \text { overweight }\end{array}$} & & \multicolumn{2}{|c|}{$\begin{array}{l}23 \% \\
47 \% \\
30 \%\end{array}$} \\
\hline \multicolumn{2}{|c|}{$\begin{array}{l}\text { As adult } \\
8 \mathrm{lb} \text { underweight } \\
\text { Normal } \\
8 \mathrm{lb}+\text { overweight }\end{array}$} & & & \multicolumn{2}{|c|}{$\begin{array}{l}10 \% \\
20 \% \\
70 \%\end{array}$} \\
\hline \multicolumn{6}{|c|}{$\begin{array}{l}\text { *Of the } 208 \text { reports } 19 \text { failed to report their weights, leaving } 189 \text { cases. Ideal weights we } \\
\text { computed from Metropolitan Life Insurance Standards. } \\
\text { †'Hypertensive' is defined as a current reading of } 150 \mathrm{~mm} \mathrm{Hg} \text { or more (systolic) and/ } \\
90 \mathrm{~mm} \mathrm{Hg} \text { or more (diastolic). }\end{array}$} \\
\hline \multicolumn{6}{|c|}{$\begin{array}{l}\text { TABle 4. RELATIONSHIP BETWEEN AVERAGE BODY WEIGHT CHANGES OVER } 20 \text { YEARS AND PRESE } \\
\text { AVERAOE BLOOD PRESSURE LEVELS }\end{array}$} \\
\hline $\begin{array}{l}\text { Student to } \\
\text { adult weight } \\
\text { change }\end{array}$ & $\begin{array}{c}\text { No. } \\
(n=190)\end{array}$ & $\begin{array}{l}\text { Present } \\
\text { mean } \\
\text { systolic }\end{array}$ & $\begin{array}{c}\text { Present } \\
\text { mean } \\
\text { diastolic }\end{array}$ & $\begin{array}{l}\text { Mean } \\
\text { systolic } \\
\text { change }\end{array}$ & $\begin{array}{l}\text { Mean } \\
\text { diastolic } \\
\text { change }\end{array}$ \\
\hline$>20 \mathrm{lb}$ loss & 2 & $148 \cdot 0$ & 89.0 & +10 & +30 \\
\hline $11-20$ lb loss & 2 & $122 \cdot 0$ & 80.0 & $+12 \cdot 0$ & +3.0 \\
\hline $1-10$ lh loss & 8 & 122.9 & 78.0 & +7.4 & +3.5 \\
\hline $0-9 \mathrm{lb}$ gain & 18 & 122.7 & 78.2 & -1.6 & $\begin{array}{l}+3.7 \\
\end{array}$ \\
\hline $10-19 \mathrm{lb}$ gain & 42 & 125.8 & 78.5 & +3.7 & $\begin{array}{r}28 \\
+28\end{array}$ \\
\hline 20-29 lb gain & 45 & 123.9 & 78.9 & +5.1 & $\begin{array}{r}2.0 \\
+1.8\end{array}$ \\
\hline $30-39 \mathrm{lb}$ gain & 41 & 125.5 & 80.3 & +4.8 & +3.3 \\
\hline $40-49 \mathrm{lb}$ gain & 25 & 128.6 & 82.7 & +5.0 & $\begin{array}{l}+5.9 \\
\end{array}$ \\
\hline$>49 \mathrm{lb}$ gain & 7 & 128.3 & 78.5 & +10.0 & +4.3 \\
\hline
\end{tabular}


Table 3 shows that adult subjects with blood pressures in excess of $149 \mathrm{~mm} \mathrm{Hg}$ systolic or $89 \mathrm{~mm} \mathrm{Hg}$ diastolic were more prone to overweight as students and tend still to be more overweight than their peers with more normal blood pressure levels. Table 4 examines the relationship between change in body weight and present blood pressure levels. It shows that the average systolic blood pressure increased with the amount of weight gained over the years $(r=0.42 ; P<0.01)$. The correlation of weight change with present diastolic levels was negligible $(r=0.06)$.

\section{DISCUSSION OF RESULTS}

We prefer not to apply the term 'hypertensive disease' to the 29 middle-aged subjects with systolic blood pressure in excess of $150 \mathrm{~mm} \mathrm{Hg}$ or diastolic pressure of $90 \mathrm{~mm} \mathrm{Hg}$ or more. The individuals are chosen for closer analysis of their antecedent history only because their blood pressure on a single occasion exceeds a currently conventional 'cutting point.' Possibly from among these 29 subjects hypertensive disease may later emerge. In the 20 -year interval between the ages 20 and 40 , the variability between two single casual blood pressure readings is so great as to mask any significant upward trend in an individual's blood pressure readings with age. A more accurate evaluation of blood pressure levels than a single casual reading is necessary before defining an individual as 'prehypertensive.'

It is possible that our population was biased by reason of the mode of selection. However, the mean blood pressure at age 20 of $121 / 76$ and at age 40 of $126 / 80$ is not far from the accepted value for a white male population [1] and shows the usual upward trend in mean blood pressure with age. Although, as Platr [2] has suggested, one may have to wait until the sixth decade for the full expression of hypertension, one would expect the youthful 'prehypertensive' at least to maintain a high normal blood pressure level at age 40 if he were destined to acquire hypertension later in life.

The presently 'hypertensive' group were heavier as students than were the present normotensives. At their present age, the 'hypertensives' are also definitely more overweight than the normotensives. The increase in actual body weight from student to adult ages showed a significant correlation with present systolic levels. The observations reported by STAMLER [3] agree with our data that formerly obese subjects in later years show a higher prevalence of clinically confirmed 'hypertension.'

Some reported longitudinal studies of the outcome of 'juvenile hypertension' are reviewed in Table 5. A greater frequency of subsequent hypertension appears among subjects with juvenile blood pressure elevations. However, most studies have compared the frequency with which the 'cutting point' in youth is equalled or exceeded in later life. Thus a student with a higher than normal blood pressure need only remain at the same level to qualify later as a 'hypertensive,' while the control population must exhibit a substantial rise in blood pressure to reach the hypertensive' classification. When this definition is used, it is not surprising that more of the 'prehypertensives' than of the normotensives achieve such a status.

Further study of these longitudinal evaluations reveal: that special populations, usually males, were selected; that the definition of later hypertension varied widely, and often barely exceeded the original limits; and that the frequency of vascular complications was not given. STAMLER [3], however, cites an increased frequency of 'hypertensive heart disease' ( 31.8 per cent) in the 22 middle-aged subjects with young 


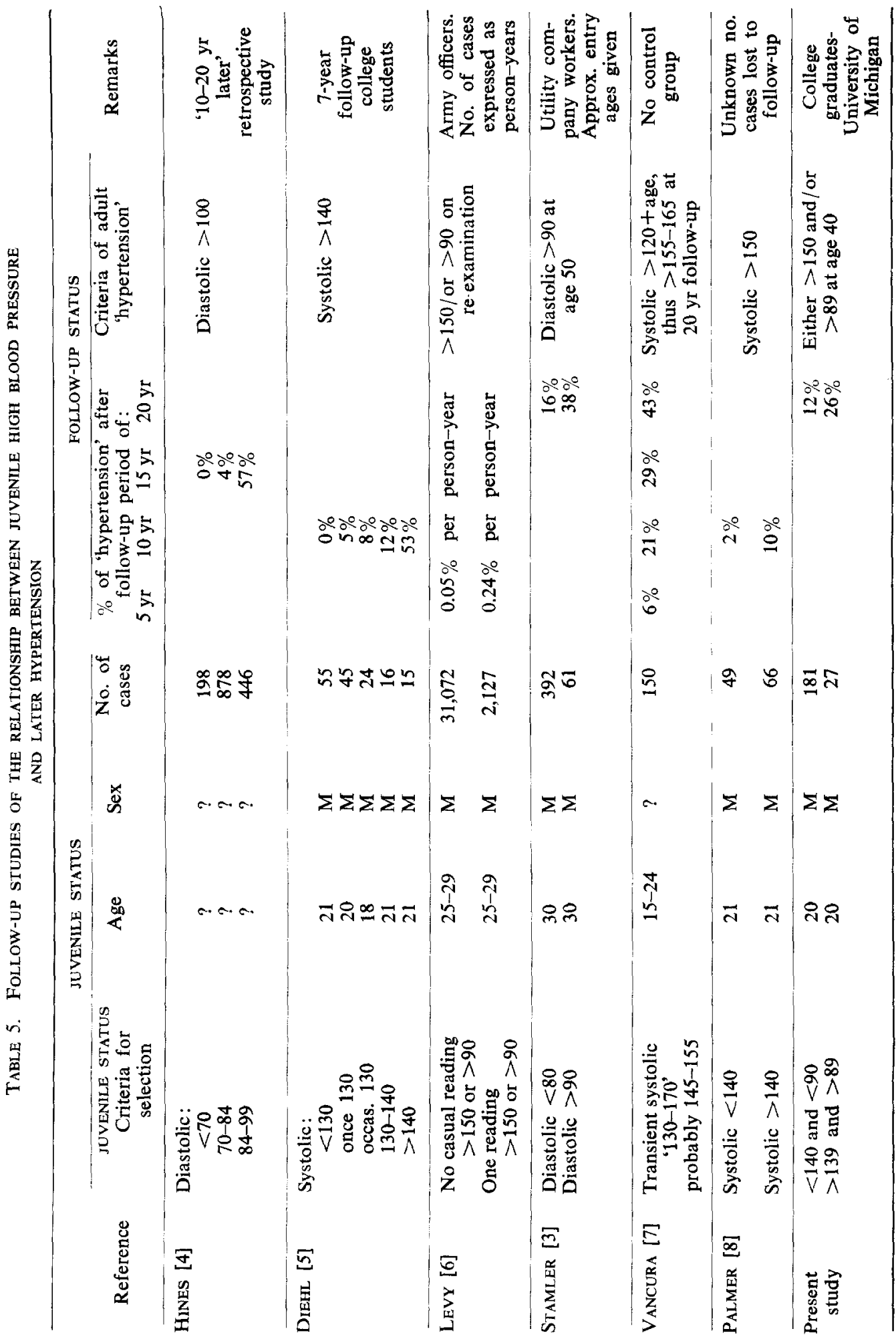


adult diastolic blood pressure in excess of $90 \mathrm{~mm} \mathrm{Hg}$ as compared to the low incidence (6.3-7.2 per cent) of this complication among 121 young men with lower diastolic levels.

\section{SUMMARY AND CONCLUSIONS}

1. The casual blood pressure of 208 male college subjects was redetermined after a 20-year interval (at an average age of 40). The frequency of 'prehypertension' in youth was 13 per cent (systolic over $139 \mathrm{~mm} \mathrm{Hg}$ or diastolic over $89 \mathrm{~mm} \mathrm{Hg}$ ) and for the 40-year olds was 14 per cent (systolic over $149 \mathrm{~mm}$ or diastolic over $89 \mathrm{~mm}$.).

2. Although the average systolic blood pressure of the group as a whole rose from $121 \mathrm{~mm}$ to $126 \mathrm{~mm}$ and the diastolic from $76 \mathrm{~mm}$ to $80 \mathrm{~mm}$ there was a poor correlation between the initial and final readings for the individual subject and the data showed a marked 'regression toward the mean.'

3. Among 27 subjects with juvenile elevations in excess of $139 \mathrm{~mm}$ or $89 \mathrm{~mm}$, seven (26 per cent) showed adult 'hypertension' (in excess of $149 \mathrm{~mm}$ or $89 \mathrm{~mm}$ ). This was about twice the frequency as for the group as a whole.

4. The reported relationship of overweight in youth, and of gain in weight to the later devclopment of systolic 'hypertension' is confirmed in our studies.

5. Other follow-up studies of juvenile 'hypertension' are reviewed and compared with the present report.

6. It is suggested that 'casual' blood pressure readings may be of limited prognostic significance, and that efforts to identify by multiple blood pressure readings the 'usual' or 'sustained' youthful hypertensive may be more meaningful in prognostic studies.

Acknowledgements-This work was supported by Grant No. H2578, U.S. Department of Health, Education and Welfare.

We are indebted to Mrs. Hugo Palmero for invaluable assistance in the collection of data.

\section{R E F E R E N C E S}

1. Boe, J., Humerfelt, S. and Wedervaug, F.: The blood pressure in a population, Acta med. scand. Suppl. 321, 1957.

2. Platt, R.: Essential hypertension: incidence, course, heredity, Ann. intern. Med. 55, $1,1961$.

3. Stamlen, J.: in Pathogenesis of Essential Hypertension, Proc. Prague Symp. p 67. Ed. by Cort, J. H., Fencl, V., HeJl, Z. and JirKa, J. State Medical Publishing House, Prague, Czechoslovakia, 1961.

4. HINES, E. A., Jr.: Vascular Reactivity and Hypertensive Disease, In Hypertension, A Symposium. University of Minnesota Press, Minneapolis, Minn., 1951.

5. DieHL, H. S., Meredith, B. and Hesdorfer, B.: Changes in blood pressure in young men over a seven year period, Arch. intern. Med. 52, 948, 1933.

6. Levy, R. L., Hillman, C. C., Stroud, W. D. and Whire, P. D.: Transient hypertension: its significance in terms of later development of sustained hypertension and cardiovascular renal diseases, J. Amer. med. Ass. 126, 829, 1944.

7. Vancura, A.: On transient hypertension in young subjects, Cardiologia 16, 124, 1950.

8. PAlmer, R. S.: The significance of essential hypertension in young male adults, J. Amer. med. Ass. 94, 694, 1930. 